\title{
A Consulting Giant; a Disgruntled Client: a 'Failed' Attempt to Change Management Controls in a Public Sector Organisation
}

\author{
M Junaid Ashraf \\ Essex Business School \\ University of Essex \\ And \\ Shahzad Uddin* \\ Essex Business School \\ University of Essex
}

* Corresponding Author 


\begin{abstract}
There has been very little research into management consulting interventions in public sector organisations especially in emerging economies. This paper aims to fill this void by narrating the empirics of a consulting assignment carried out by a large international consulting firm in a Pakistani public sector organisation. The paper found that consultants' recommendations of modern day management accounting and control practices, such as a modern performance measurement system and a 'state-of-the-art' information system, were rejected by the management, who stopped the balance of payment of the consultants' fee. Employing a theoretical perspective that focuses on the structural conditions facing both the client and the consultants, and the strategies adopted by the consultants and the client, the paper aims to explain the empirics of the case. Through identification of the structural conditions operating in emerging economies, this paper sheds light on the nature of the relationship between consultants and client in these settings. The consultants' strategies and what went 'wrong' with these strategies was also analysed. Client management counter-strategies and management's reasons for implementing them were also explored. Thus, through structural and strategic analysis, this paper aims to enhance our understanding of the dynamics of management consulting in public sector organisations especially in emerging economies.
\end{abstract}

Key Words: Management Consulting, Modern Management Control Practices, Public Sector, Emerging economies, Pakistan 


\section{Introduction}

This paper is concerned with the management consulting interventions in the Civil Aviation Authority (CAA), a Pakistani public sector organisation. This paper is part of a larger research project on management accounting changes in public sector organisations in emerging economies. Comparatively little research has been conducted into management consulting in the public sector (Lapsley and Oldfield, 2001). What is even rarer is research on management consulting in public sector organisations in emerging economies. More individual country studies are crucial to trace patterns and exceptions of management accounting changes (Hopper et al., 2009).

There has been a 'movement' since the early 1980s to bring about changes in the public sector governance model of organisations, such as NPM, especially in the developed world (Hood, 1991, 1995; Pollitt, 1995). Diefenback (2007) explains, "It [NPM] is an (inconsistent) set of assumptions and conclusions about how public sector-organisations should be organised, run and function in a quasi-business manner. It might be defined as a strategic initiative, if not ideology, to make public sector organisations - and the people working in them - "market-oriented" and "business-like", i.e. performance-, cost-, efficiency- and audit-oriented" (p.127). Since the change involved in bringing the management practices prevalent in the private sector into the public sector, the role of consultants in this regard cannot be ignored. Hood (1995) argues, "[An explanation] of the rise of the New Right would ... need to place more stress on the eclipsing of the old public administration coalition (particularly the public service labour unions) by an NPM coalition drawn from accounting firms, financial intermediaries, management the consultants and business schools..." (p.10). Consultants have a big role to play in this change, as is evident from the large sum of money being paid to consultants by the governments of developed countries 
(Lapsley and Oldfield, 2001). While there is some research into the role of consultants in bringing about changes in public sector organisations, almost all researchers have recognized the need for more in-depth research (Laughlin and Pallot, 1998; Lapsley and Oldfield, 2001; Saint-Martin, 1998).

As far as emerging economies are concerned, accounting literature contains examples of a number of public sector organisations that have been subject to management control changes. These changes have often been triggered by the privatisation of public sector firms (Uddin and Hopper, 2001; Uddin and Tsamenyi, 2005) sponsored by the World Bank's reform programs (Hopper et al., 2009; Uddin and Tsamenyi, 2005). In most of these cases, changes (or change efforts) are involved in bringing more private sector practices into public sector organisations. While not abundant, there is a certain amount of evidence of consultants' involvement in bringing about management accounting changes (Nabiha and Scapens, 2005). However, detailed research on management consulting within public sector organisations in emerging economies is nonexistent. Thus, this paper intensively investigates a consulting assignment for management accounting change in a public sector organisation in Pakistan. The paper employs an 'integrated' perspective advanced by Fincham (1999) to explain the role of management consultants, the clients, structural constraints and their impact on organisational changes including management accounting changes. Applying a critical realist methodology, the 'integrated perspective', as is explained later in the paper, provides a more robust explanation of consulting interventions. Its fundamental premise is that the management consulting interventions in organisational changes need to be understood by due attention being given to both structural and strategic (agency) issues.

The paper is structured as follows. After the introduction, the second section explains the notion of 'integrated perspective' drawn from previous research on management consultants in general. 
Then, following the section on background information about the company and the consultants' report, it discusses the underlying methodology of the 'integrated perspective' and data collection methods. The structural constraints, clients and consultants' strategies are discussed in the next section. The final section provides the concluding remarks.

\section{Previous Research and Theoretical Framework}

Fincham (1999) broadly categorises research streams that deal with management consulting: functional and critical research streams. In the functional research stream, consultants are seen as specialists having the requisite knowledge, which is lacked by managers, but is required to adapt the firm to the rapidly changing business environment, such as global competition, technological advancements and so on (Clark, 1995). The objective of the consultants' intervention is to increase the efficiency of the firm and, resultantly, corporate profits. The majority of these studies deal with techniques of intervention, stages of interventions and so on (Fincham and Clark, 2002). Predominantly, writers in this stream of research were themselves management consultants and, as such, there was a vested interest in their writings to glorify consultants and the techniques that they adopt. This stream of research was, as stated by Alvesson and Johansson, (2002) on consultants, by consultants and for consultants.

Contrary to functional research, critical management studies problematise the taken-for-granted utility and importance of management consulting and the role they play in bringing about changes to management and accounting practices at the organisational level (Baritz, 2005). Some studies went on to question the knowledge base of consultants. For example, Alvesson and Johansson (2002) argue management consultants are not professionals in the strict sense of word given that they possess no domain knowledge, that is, no codified body of knowledge, no entry regulations and so on. The focus of critical literature has been on how and why there has been a widespread increase in management consultants' services in recent decades, despite their uncertain 
knowledge base (McKenna, 2001). What has led consultants to become such 'powerful actors' in the organisational arena despite them being 'outsiders'? Alternatively, to what extent are consultants really powerful and to what extent are they just another set of players in the capitalist game of sectional interests? Whatever the answers to these questions, the question of the relationship between client and consultant remains at the heart of the critical literature on management consulting. Put simply, two sets of perspectives have attempted to address some of those questions on consulting within critical management traditions, namely, strategic and structural (Fincham, 1999).

Research within the strategic perspective focuses mainly on 'strategies' employed by consultants to sell their services to clients. Given that there is no domain knowledge, how is it that that consultants end up selling a lot of consulting services to client managers? According to critical researchers, the answer lies in a number of symbolic strategies employed by consultants to win clients. These strategies include, for example, the use of glossy brochures, seemingly scientific methodologies, the consultants' appearance of professional competence and use of technical jargon, and so on (Clark, 1995). Consultants use a set of rhetorical techniques to create an 'impression' of the utility of their patented solutions (Alvesson, 1993; Clark, 1995). Certain critical researchers have equated consultants' strategies with dramaturgical acts (Clark, 1995), story telling (Clark and Greatbatch, 2002) or fantasy themes (Jackson, 2002). In any case, it is an act of persuasive communication where the actor on the stage is the consultant whereas the somewhat passive participants in the game are the clients sitting in the hall as spectators (Fincham, 1999). Consultants play on clients' insecurities, heightening them to a point where it becomes easier for consultants to sell their 'seemingly attractive solutions' to clients. This perspective obviously gave primary importance to the consultants and their strategies whereas clients became, as described earlier, somewhat passive players who could respond to consultants' strategy only in terms of acceptance or even resistance, while remaining in a secondary role. 
Nevertheless, recent researchers seek to extend the strategic perspective approach by focusing on the complex processes of consumption which was ignored by previous studies (Collins, 2003, 2004; Gabriel, 2002; Abrahamson \& Eisenmann, 2001). Collins (2004) argues that 'the normal application of the cookbook or recipe motif distorts our appreciation of the nature of consultantclient relations because it portrays the users of management advice as passive recipients of readymade and readily applicable consulting practices. Noting that cookbooks and recipes - whether these be culinary or organizational - tend to demand tools, knowledge and/or 'ingredients' that are seldom readily available to the user, we argue that there is a need to acknowledge the ways in which consumers tend (variously) to transgress, transmute or even transcend culinary and organizational recipes' (Collins, 2004, p. 556).

Research within the structural perspective focuses on explaining the widespread use of consulting through large scale structural forces operative on managers working in capitalistic organisations and this includes clients as well as consulting firms (Sturdy, 1997). Managers operating in capitalistic organisations due to their positions face pressures, compulsions and insecurities. From a Marxist perspective, managers are the agents of capitalists who feel compelled to extract the maximum benefit from labour to satisfy the capitalists. There are various management groups (for example, accountants, Information Technology professionals and so on) within the organisation who are also trying to win the confidence of capitalists and to weaken other groups' positions, and who eventually emerge as victorious over others (Armstrong, 1989). Then, on top of this, the politics of professions and control of labour is the competition between capitalistic firms and senior managers who, given the positions they occupy, feel bound to provide a satisfactory return to the capitalists while ensuring their own vested interests are safeguarded, for example, promotions, pay rises and avoiding redundancy (Armstrong, 1989). Sturdy (1997) contends that the hiring of consultants may well be a ploy adopted by managers to safeguard their 'positions' against threats posed by rivals and lower level managers and labour in that it indicates to the 
managers' peers that the managers hiring the consultants are abreast of the latest techniques and information in the field of management and, of course, are lending a hand to control the workforce. In this sense, the widespread use of consulting can be attributed to the effect of managerial structures operating within corporations, which, in turn, are operating within larger capitalistic economic structures. The structural approach thus accords less importance to the persuasive techniques used by consultants for the widespread use of consulting services, but emphasises more the structural context of clients (Sturdy, 1997a, 1997b). Lower level employees and those managers who have not hired the consultants tend not to feel sympathetic towards the consultants and resist the consultants' interventions within the organisation. Thus, resistance to the consultants' efforts is also an effect of the structural factors operating on managers within capitalistic organisations (Sturdy, 1997a, 1997b). Employees and managers of consulting firms (being capitalistic organisations) feel the same pressures and insecurities as client-managers. It is imperative for them to bring in more business and complete successful consulting projects and thus they will try to address some of the clients' concerns in a pre-emptive manner (Sturdy, 1997a 1997b). So, the whole extent of the involvement with consulting is explained in the 'structural approach' through the effect of pressures faced by 'positions' operating within capitalistic organisations. This is in contrast to the strategic approach whereby the emphasis is on the agents in question, i.e., the consultants and their strategies devoid of any structural pressure.

While there are clear rationales for looking at things from a strategic or structural perspective, Fincham (1999) notes that these two approaches are not mutually exclusive, and integrating the two approaches leads to more robust explanations of management consulting interventions. Thus, in order to understand the role of consultants and clients in management accounting changes in a a public sector organisation in Pakistan, the paper seeks to give due attention to both strategic and structural factors. Drawing on Fincham's (1999) idea of an integrated perspective, the operational questions set out in this study are as follows: What are the structural constraints faced by CAA? 
What are the strategies employed by the management consultants? How did the client managers (in this case CAA's management) react to the consultants' suggestions on management accounting change? How did the interactions between structural constraints and strategies influence the outcomes of the consulting interventions?

\section{Methodology and Data Collection Methods}

It is important to note that the 'integrated perspective' suggested by Fincham (1999) is the classic individual (agency) versus society (structure) debate in sociology ${ }^{1}$. While this has been an ongoing debate in sociology for more than a century now, there are sociologists who, in relatively recent times, have suggested that better social explanations will involve some kind of an integration of these two approaches. The most notable sociologists and their theories are Giddens' (1984) Structuration theory and Bhaskar's $(1975 ; 1979 ; 1997)$ Critical Realism². While Giddens' (1984) conceptualization of structure and agency has been widely used in management and in accounting research, it is Bhaskar's conceptualization of structure and agency, which is not often used by accounting researchers, that we would like to appropriate for this paper $^{3}$ (Llewellyn, 2007; Modell, 2009). For the critical realist, structure is a system of relationships between objects, positions and collectivities that explains their tendencies to act in a particular way. So, for example, businessmen in a capitalistic structure (the relationship between capitalists, labour, the product market and so on) will have a tendency to compete fiercely with other businessmen and try to drive them out of business.

However, outcomes in the form of events are not pre-determined by structural tendencies. At times, instead of driving each other out of business, businessmen cooperate with each other by forming a cartel. So, structures under one set of conditions will generate one set of events and under another set of conditions will generate another 4. Each position within the relationship has certain powers, resources and constraints. Structures do not act like hydraulics on incumbents of 
positions within this system of relations. Bhaskar and other scholars subscribing to his school of thought fully recognize the importance of agency, i.e., the power of individuals to interpret and reflect on these structural pressures and take actions that they deem appropriate, even against the structural pressures. Structure influences the incumbent of a position within a system by vesting each position with interests. However, it is up to the incumbent of the position to recognize the interests. He or she may not be able to recognize their own interests or, even after recognizing them, may decide to act against them, though this may result in a loss, including loss of position. A capitalist who does not compete with other capitalists may cease to be a capitalist (Porpora, 1992)5. In the case under discussion, theoretically and methodologically, the foremost issues that require investigation are how to identify the structures at work and the interaction of these structures with the actions of agents. In order to identify the structures at work here, the paper has used Sayer's (1992) series of questions, which he suggested are most useful for identifying structures of interest: "What does the existence of this object (in this form) presuppose? Can it exist on its own as such? If not, what else must be present? What is it about the object that makes it do such and such?” (p.91). These questions, as suggested by Sayer (1992), may appear simple, but the answers can be quite complex and can help in identifying objects and positions that together form a structure. Throughout the data collection, these questions were the guiding light that helped in tracking through the data site.

In terms of the relationship between structures and the actions of agents, the paper utilizes Archer's (1995) methodological guidelines ${ }^{6}$. It is imperative, from a methodological point of view, that the powers, susceptibilities and interests of positions are identified before the interaction sequence of the present generation of actors is captured. A public sector organisation that is controlled by another Ministry or Department, which, in turn, is under the control of the government together with associated institutions, constitutes a larger structure (Willmott, 2000), i.e., a system of interrelated positions. The powers, interests and liabilities of these positions need 
to be understood before any attempt is made to make sense of the actions and strategies of actors and how these actions lead to certain outcomes. In this case, the data collection efforts were targeted at understanding the structural conditions that were being faced by the senior management of CAA before the consulting assignment was commissioned. At a general level, these structural conditions should not be radically different from those faced by other public sector officials. So, data collection was undertaken by reading news reports relating to CAA and other similar public sector organisations that had appeared in the national and international press media in the previous five years. These news reports proved very useful for developing a general understanding of the structural conditions being faced by the managers of public sector organisations in general in the country. The first author also had unrestricted access to all official documents including directives written by successive Director Generals, office memos and minutes of the meetings of the board of directors. This also facilitated an understanding of the context of change and the thinking of higher management at the time of, and before the change. The paper also had access to archival data including financial statements, operational records and other organisational data, such as old official publications and so on. All of this helped in developing a better understanding of the organisation, its operations, its systems, its procedures and the rationale - the systems, procedures and operations. Fifty interviews were conducted. Interviewees were either working for the organisation or had worked for the organisation previously. Some of the interviewees were also amongst the earliest employees of the organisation including the first Director General of the organisation and the first General Manager of Finance. The span of the data collection phase was around six months. Each interview ranged from one to two hours. Notes were taken during the interviews. Care was exercised to ensure that there was a good mix and representation of interviewees in terms of their hierarchical position within the organisation as well as years of experience (see Table 1). The wide range of interviewees ${ }^{7}$ enabled us to deepen our understanding of the structural conditions being faced by the managers in question. At the same time, it also gave an insight into the 
understandings of the actors involved and the actions that they took based on those 'understandings'. It is important to mention that this research paper focuses only on the consultancy aspects of the project. The results, methods, and underlying theories from this project on other aspects of research into management accounting change will be reported in papers in progress.

\section{Case Study: Civil Aviation Authority}

CAA was formed in 1983 through a presidential ordinance as an autonomous government organisation to regulate the aviation industry and to manage all airports within the country ${ }^{8}$. The mission of the organisation as per the ordinance was "to provide safe and comfortable air journeys to passengers in an economically efficient way". CAA comes under the ambit of the Ministry of Defence. The Secretary of Defence is the ex-officio chairman of the Board of Directors. The organisation's affairs are run by the Board of Directors and the Director General of the authority (Chief Executive Officer) who is appointed by the Federal Government for a fixed period of time. Nevertheless, not surprisingly, CAA has been subjected to interference from the federal government even regarding day-to-day affairs. This interference was reported by all the senior managers of CAA that were interviewed starting from the first generation of senior managers who took charge of the organisation at its inception to the current managers. In terms of organisational structure, from early on, CAA was divided into seven functional areas called directorates, each of which was headed by a director. These were Directorate of Operations (responsible for air operations as well as airport management), Technical Directorate (responsible for all engineering functions), Directorate of Projects (responsible for overseeing capital projects), Directorate of Works (responsible for civil works), Finance Directorate, Inspectorate of Regulatory Board (for regulatory functions) and Directorate of Administration. Directorates and their functioning have not altered since their creation, except for the fact that the number of 
directors increased from 7 to 16 in 2005 , i.e., the time when the consultants came in. Over the years, some new functions were added (e.g., Directorates of Legal Affairs and Commercial Affairs) whereas some earlier functions were divided into two or three directorates. For example, in 2005 , there were four directorates responsible for different aspects of regulation, namely, the safety investigation board, the air transport service, air worthiness and flight standards.

As far as financial data are concerned, the accounting information system of CAA was computerised in the late 1980s. At present (and at the time of the consulting assignment), all financial information from various major airports and project sites is sent to Head Office in electronic form. The rest of the airports send details of transactions to Head Office where these are entered into the computerised accounting information system. So, at the time of the consulting assignment, CAA had detailed accounting information about all the income statement items of the various airports/project sites.

\section{[Insert Table 2]}

Table 2 indicates the financial performance from 2001 to 2005 (just before the management consultant's interventions). The fieldwork revealed that, like the majority of public sector organisations in Pakistan, CAA has never been a loss-making concern since its inception. Even though the net surplus was reduced sharply in 2001 and especially in 2002 (mainly due to the impact of 9/11), it has been rising since then. Table 2 also highlights the economic efficiency in terms of Rupees spent per activity of CAA, which went down in 2002 and 2003, but started improving significantly in 2004 to the extent that, in 2005, CAA was performing these functions at a lesser cost than in 2001: the money spent on handling each passenger was Rs. 0.43 per passenger as compared to 2001 when it was Rs. 0.45 per passenger. This is the case with three 
other operational measures highlighted in the table. The figures show still better results in recent years even when the inflation rates are adjusted.

\section{The Consultancy Assignment}

The beginning of the consultancy assignment for CAA is partly rooted in the efforts by the Pakistani government at that time to bring 'good governance' to public sector entities inspired by the World Bank and IMF induced structural adjustment programs (Hopper et al., 2009; Zaidi, 1999). Commentators also argued that internal politics and the then Prime Minister's background ${ }^{9}$ may have played a significant role in introducing private sector initiatives into the Pakistani public sector (Al Ahram Weekly, 01/07/2004). Whatever the cause, the higher management of CAA, to their surprise, were called in by the Prime Minister's secretariat to give presentations about their 'performance'. One senior manager commented, "CAA is a relatively small organisation. Why is it that we were asked by the Prime Minister to make a presentation, almost immediately after he had assumed office? Surely there had to be an ulterior motive to this". Nevertheless, the reason for requesting this 'action' from CAA remains a mystery given that there were a large number of public sector organisations much bigger than CAA that were running at huge losses. The results of the meeting between CAA and the Prime Minister's secretariat came as an even greater shock to the CAA top management. The top management team of CAA was composed predominantly of military personnel (serving or retired) and civil bureaucrats headed by a serving Air Vice Marshall. One manager recalled, "The Prime Minister asked us, "Where is your Business Plan?" Then asked us, "Where is your CFO?" We didn't have any answer. In fact we didn't even know what he was talking about!" The Prime Minister's personal interest in reforming the CAA kept the CAA management alert by putting the performance and future prospects of CAA in the cabinet meeting agenda. According to one newspaper report ${ }^{10}$, the cabinet was informed that 
"Airports at Lahore and Karachi had been constructed by the CAA after obtaining huge loans from international and local consortia ${ }^{11} \ldots$ and only the Karachi, Islamabad and Lahore airports were yielding profits to the CAA while operations at a large number of airports in different parts of the country were being subsidized".

Moreover, the cabinet directed CAA, which at the time was headed by a serving Vice AirMarshal and was staffed predominantly by military and air force officials and technical people (predominantly engineers and other aviation experts) to make a 'credible and viable business plan' within 30 days. The cabinet further explained that 'a credible and viable business plan should include an accurate picture of revenue, assets, liabilities, proposals for income generation from international as well as domestic routes, its land bank, constructed premises and potential for tourism"12. This business plan was supposed to be presented before a ministerial committee headed by the Prime Minister.

Given the urgency from the Prime Minister's secretariat, the senior management decided to hire the services of a team of consultants. A major international consulting firm, McKinsey Ltd., was hired in early 2005 for the purpose of preparing a business plan for CAA as requested by the Prime Minister. Since CAA management decided to hire the services of consultants to prepare the business plan, it inevitably resulted in easing the time pressure that was being exerted by the Prime Minister's Secretariat. It was an expensive assignment, as is the case with all consulting assignments done by large international consulting firms ${ }^{13}$. Nevertheless, CAA was handed a 16page consulting assignment report in June 2005. The title of this report was 'Business PlanReorienting CAA'. The first page of the report claimed that this reorientation should result in

"CAA reaching USD 1 billion in value as compared to a current value of close to zero" (Business Plan-Reorienting CAA, p.1). 
So, the new vision of this public sector organisation was declared as 'becoming a USD 1 billion firm'. In order to achieve this vision, the consulting report recommended certain 'strategic enablers' and 'strategic initiatives'. The key suggestions and associated strategic enablers and initiatives recommended are discussed below.

The report asserted that there were conflicts between the demands of airport management and regulation that, in the absence of clear decision criteria; resulted in decision-making being moved up the organisation hierarchy or into Ministries. The report mentioned:

Conflicts may arise about granting additional routes: Whereas the airports would appreciate any additional connection, the regulator must consider a different set of factors and may be subject to interference by other government institutions. Furthermore, no clear ranking or direction has been given to the individual roles, making prioritisation between different objectives difficult for management of the CAA. Hence, many decisions are taken at the Board level or even at the Ministries (ibid. p.3).

The suggested recommendation consisted of two 'strategic enablers'. First, independent management for airports was considered vital to the reform. The report suggested an administrative trifurcation of the organisation with three units headed by three deputy DGs (new positions to be created). The consultants also suggested three new mission statements for the three functions. The second problem identified by the consultants was the lack of any business skills, information system or decision-making rights for executives. The solution was thus simple: Hire fresh 'real-life business experience' at competitive prices; give them a 'state-of-the-art information system' and give them decision-making powers. The consultants recommended creating fresh positions for a Director of Finance (to install the required information system), a Director of Commercial Aviation ('to develop contract management skills and key account strategies towards airlines') and a Director of Operations ('to drive the continuous improvement process at the airports given the importance of getting operating costs under control'). In addition, 
the consultants also suggested doing away with the fixed term appointments and instead recommended the adoption of a system including 'targets', 'performance reviews', 'financial incentives for achieving target' and 'option to dismiss managers for underperformance'.

The report also emphasised a number of 'strategic initiatives', such as the development of real estate for large chunks of vacant land lying around Lahore and Karachi airports. The report highlighted the importance of developing retail activities at the airports for which they suggested hiring the services of commercial managers and new consultants. Airport networking was another 'strategic initiative'. The report commented,

Only four airports generate operating profits for the CAA... [t]he other airports eat up almost half of that profit. In order to optimise the airport network, we recommend assessing the unprofitable airports and developing strategies to either close or develop these (ibid., p.10).

In addition, the consultants suggested creating passenger hubs, primarily in Karachi and to a lesser extent in Lahore. According to the report, opening up international routes from too many airports had reduced the number of passengers passing through the larger airports, such as Karachi, thus making it unattractive for international airlines, especially European and North American airlines, to start their flights to Pakistan. The consultants thus suggested that all other airports should feed passengers to Karachi so that Karachi would become a hub of passengers and resultantly attractive to foreign airlines. Taking this line of argument, the consultants also questioned the rationale for the new Islamabad airport (CAA had already embarked then on the planning phase of the airport).

The consultants also expressed concerns at the labour productivity: 
"At this point, labor productivity is very low and labor costs are the main driver for projected downturn in profitability" (ibid., p.13).

It was suggested that an improvement in the core processes would result in freeing up labour that, according to the consultants, would be used in other activities, once the amount of aviation traffic increased. The top contenders identified for process improvements were passenger throughput, aircraft turnaround, cargo throughput and airport maintenance.

\section{Discussions: structures and strategies}

\section{Structural Constraints}

The structural configuration in which managers of public sector entities operate, exposes senior managers (agents occupying senior manager 'positions') to pressures and insecurities that differ from those of typical capitalistic firms for some obvious reasons (Uddin and Hopper 2001; Uddin and Tsamenyi, 2005; Tsoukas, 2001). These are even more pronounced in poorer countries such as Pakistan (Wickramasinghe and Hopper, 2005). A number of studies conducted by Transparency International and National Anti Corruption, supported by the fieldwork for this study, concluded that the relationship between managers of public sector organisations in Pakistan and political office bearers is such that senior managers are in a particularly weak position vis-à-vis the politicians holding public office. There are two powers associated with those in positions of political office vis-à-vis managers of public sector organisations due to which they feel insecure and thus compelled to obey the instructions of their political bosses. These are, first the threat of purging managers from office, and second, transferring managers to positions that lack privileges and perks (National Anti Corruption Study, 2002 and Transparency International Country Study on Pakistan, 2003). The lack of an efficient judicial system makes the managers even more vulnerable regarding orders coming from ministers that they do not 
deem appropriate (Transparency International Country Study on Pakistan, 2003, p.56). This structural environment, in effect, makes managers relatively free of (financial or otherwise) performance and efficiency considerations, but ultra sensitive towards political preferences. This is primarily because politicians are least concerned with the profitability and performance of departments and organisations under their charge. Given Pakistan's political system, these politicians come to power having spent a considerable amount of their own money on the election (National Anti Corruption Study, 2002, p.17). Their first consideration after winning the election is to recover this investment and to ensure that they win the next election. This causes them to interfere with the affairs of public sector entities. This interference can take various forms; for example, appointing undeserving candidates to gain political mileage or bribes or both (National Anti Corruption Study, 2002, p.26). Consequently, "most senior managers are less concerned with the organisation's service delivery and more about appeasing the ministers and prime minister.” (National Anti Corruption Study, 2002, p.24)

In the case of CAA, the Ministry of Defence, the Prime Minister's secretariat, government bodies, such as the Auditor General and the Parliament-Public Accounts office, together constitute a structure - a system of interconnected entities and positions.

\section{[Insert Figure One]}

There are certain ex-officio positions on the board representing and protecting the interests of various government entities. For example, there is a nominee from the Ministry of Finance, a nominee from Pakistan Air Force, a nominee from the Ministry of Defence (normally the joint secretary of aviation division within Ministry of Defence) and the Chairman of the Board is an ex-officio position that goes to the Secretary of Defence. There are two members on the board that are from the private sector, but they are appointed by the federal government. The Director 
General of CAA, the executive head of the organisation, is also appointed by the federal government. However, the Ministry of Defence (hence the Minister of Defence) has the power, for example, to overrule any executive decision made by the CAA officials including decisions made by the Director General. The Minister of Defence reports to the Prime Minister and thus the Prime Minister and his secretariat hold the key power vis-à-vis the federal government-controlled entities such as CAA. Given the power to appoint or remove any senior official or member of the Board of Directors without giving any justification, these appointees feel 'compelled' to obey any order that comes from the Primer Minister or his/her secretariat. The power balance between the position of the Director General of CAA and the Prime Minister of Pakistan and the feeling of helplessness it creates within the incumbent of the position of DG is best explained by an event in 1998, when the then Prime Minister of the country allegedly ordered the then DG of CAA not to allow a particular PIA aircraft to land (Dawn News 15 January 2002). On board this aircraft was the then army chief (Khan, 2002) ${ }^{14}$. There is an intense pressure on senior executives and Board members to ensure that they comply with orders coming from a minister's office or the Prime Minister's secretariat. As one former DG opined, "How can a public servant ignore the orders of the Prime Minister, even when he considers them inappropriate? He should either resign then... But then you cannot resign ... public servants have children to feed as well." These scenarios put a different type of pressures on managers in public sector organisations, such as CAA, unlike their counterparts in private sector organisations. Profit seems not to be the prime demand of the political masters of CAA and hence is not the main worrying factor for senior managers. To put it in context, there have been allegations and court cases of massive inductions of employees in public sector organisations, including CAA, during two tenures each of two Prime Ministers from 1988 to 1999 (The News International 17 August 2008; The Nation 14 August 2009). The interviewees complained on a number of occasions that they tend to receive orders (often via telephone calls) from the leaders of political parties in power to appoint employees within the organisation beyond the functional needs of the organisation, as do their counterparts in other 
emerging economies (Hopper et al., 2009; Uddin, 2009). Thus, performance measurement, not surprisingly, is relates to compliance with orders whether they come within the ambit of law or otherwise rather than the financial success only.

However, the problem for the executives of CAA is that they not only have to please senior political office holders, but also have to worry about other structural pressures. There is a web of institutional arrangements that can hold senior managers accountable for their actions. For example, for CAA, this institutional arrangement includes the office of the Auditor General of Pakistan, which carries out propriety financial audits. There is also a public accounts committee of parliament that can call upon senior managers of public sector organisations and hold them responsible for their actions. There is a National Accountability Bureau that can investigate the affairs of any public sector organisation where there is any suspicion of wrong doing. One former Director General pointed out, "You see, they may call you to explain your actions long after you have retired from the position." Another former DG explained, "The most important thing that I have earned during my service is izzat (honour). I cannot let any thing cause any harm to it." Even if nothing is proved against the officer, the fear of reputational damage is great, especially in a closely knit society like Pakistan where one person is related to so many others through either cast, kin or creed (Jones and Davenport, 1972; Anwar, 1995). These institutional arrangements normally come into action when one government's tenure is over and another government comes into power. That is the time when all old files are opened and explanations are called for. Even an action with good intent can later be termed as 'illegal' to discredit the previous government and its functionaries. Managers of public sector entities are very much aware of these eventualities. One director revealed, "You see, to make a note on a file is an 'art'. Some officers are so careful that instead of writing 'approved' on a file, they will only make a note 'seen' and give verbal instructions to their juniors regarding how to progress. This ensures that someone else will be considered responsible if the action is called into question later on. I have seen in CAA over the 
years some very careful officers who mastered this 'art'." The managers of CAA thus have to tread on a very dangerous territory where they tend to comply with both the illegal and legal orders of the politicians in power and, at the same time, have to protect themselves from legal repercussions that may occur when the present government leaves office.

The above conflicting pressures often force senior managers to elicit cooperation from, or exercise control over middle managers. The rules of the business within public sector firms require extensive documentation and multiple layers of authorization and approval. When an order comes from senior politicians,, senior managers need to carry it out and, at the same time, ensure that the rules and regulations do not appear to have been violated. Middle level managers (especially clerical staff) know these rules very well and hence also know how to bend them. Furthermore, all business decisions need to be properly approved and documented, which means that official files, in accordance with the rules, require the signatures of middle level managers as well. This often presents an opportunity to the subordinates to place some pressure on senior managers. Describing the plight of senior managers resulting from the persistent interference from senior politicians, Transparency International's study on corruption says,

"So weakened have the senior managers become ... that they themselves at times are at the 'mercy' of crafty subordinates who monopolize knowledge of the rules and regulations" (p.24).

\section{Appointment of Consultants: structural constraints and client's strategy}

When the Prime Minister's secretariat demanded a business plan immediately, something needed to be done on an urgent basis. Displeasing the higher authority was something that the senior management of CAA could hardly afford. The appointment of consultants to prepare a business plan was thus a carefully crafted move by the senior management that enabled them to relax the 
pressure that was coming from the Prime Minister's secretariat and at the same time enabled them to, in their opinion, obtain a business plan that would have credibility due to it having been produced by a well known consulting firm. The then DG of CAA commented on the process of the consultants' appointment: "We appointed a committee of the board to oversee the whole process of finalization of consultants for the job. This committee was headed by myself ... [But] you see, I am obviously not an expert on business matters, so we included these two gentlemen (private businessmen on the board of CAA recently appointed by the Prime Minister) who have the relevant background. A due process was followed to ensure that there would be no allegation of impropriety later on. We formally advertised for the consulting firms asking for 'expression of interest'. I think around eight firms expressed interest. Then there was a short listing process after which three firms were left. These three firms were then asked to submit their quotations for the job. The final decision was again made to satisfy the higher authority and at the same time to save themselves from any eventual questioning by a public sector body. Now, McKinsey was not the least expensive bidder for the job; McKinsey was appointed by the board considering its international reputation. You see, the problem with public servants is that they do not want to do something about which they can be caught out later on. We thought that if there were ever a question as to why we chose a particular firm for this important assignment, McKinsey would be the most defensible choice. If a local firm is suggesting something, it may not be that credible. If, on the other hand, McKinsey is suggesting something, everyone will pay attention to it". The choice of McKinsey would also have saved them from any possible future trouble that might have come from the Prime Minister's secretariat:

There are various reasons found in the literature for the appointment of the consultants in organisations. Commonly cited reasons include the persuasiveness of consultants, the need for further control over lower level employees, as a signal to a competing group of managers that the managers who have hired the consultants are in the vanguard of their field and so on (Sturdy, 
1997 a\&b; Huczynski, 1993). In this case, the consultants were hired as a strategy to relax the Prime Minister's pressure to present a business plan urgently and, at the same time, to ensure that one would be delivered to him in due time with which he would be more or less satisfied. In fact, senior managers were not even convinced of the utility of a business plan and they considered the Prime Minister's personal interest in seeing the business plan of an entity like CAA as 'unnecessary' to say the least. The same sentiment was shared by many other senior executives. This was reflected in the comment by one executive: "There are several hundred loss-making organisations in the country (CAA is not). Why does he not focus on those?" The motivation for hiring the consultants in this case compared to other cases documented in the literature is understandable. Those were cases of capitalist organisations where structural pressures and associated anxieties facing senior management differed from this case. In CAA, there is no pressure of profit, labour intensifications, stock market incentives and no uncertain markets (the organisation has a monopoly over the services it provides in the country). These concerns, uncertainties and insecurities are absent in public sector organisations like CAA. Structural forces operative in public sector organisations expose managers to different kind of threats and lead them to take different courses of action; these include the motivation for hiring consultants.

\section{The consultants' report: Strategies}

The consultants' strategy included the use of all the standard ammunition normally found in a consultants' arsenal (Clark and Greatbatch, 2002; Alvesson, 1993). This began with the use of symbolic tools, such as business jargon, like 'strategic enablers' and 'strategic initiatives'. Other strategies adopted by the consultants to sell their solution included 'heightening client insecurities and coming up with attractive alternatives', 'suggesting means for intensifications of workforce' and 'comforting senior managers to curb any possible resistance'. Consultants sell their solutions 
to clients by making them more and more conscious of their insecurities and deficiencies (Fincham, 1999). This enables them to sell their 'solutions' to clients with ease. This same strategy as employed by the consultants was reflected in the underlying message in the report that what is most important is profitability, but there is a lack of knowledge and skills within the current setting in enhancing profitability so follow these (private sector) management techniques. These are elaborated below.

In CAA's case, the report made it clear that it was time to 'reorient' the organisation in order to achieve the aims of the business plan. The report contended that the new focus or direction of CAA should be profitability. An organisation whose previous vision was 'to ensure the safety and comfort of passengers in the air and on the ground in an economically efficient manner' was supposed to work towards a new vision crafted by the consultants, specifically, "To become a 1 billion dollar firm". While the previous vision of the firm gave top priority to passenger safety and comfort ${ }^{15}$, the new vision was completely unbalanced. The report seemed to focus not on passenger safety and comfort, but on the economics of organisational activities. This new vision was then linked to the newly defined mission statements of the three core functions of CAA, i.e., airport management, air traffic control and regulatory services. The new mission statements made it clear that the important issues were the turnover (volume of passengers), cost management and return on investment. So, even in case of air traffic control and regulators, the safety of passengers was important, but it was not an end in itself. It is a means to an end. The end was to increase volume, i.e., turnover - the first line of the income statement. The report comments,

Since the opening of the Northern gateways, feeder traffic to Karachi and Lahore has been replaced with direct international connectivity, reducing travel time and costs for passengers. At the same time, however, international traffic has been fragmented and demand for international connections from Karachi is now much lower than five years 
ago... No Pakistani airport currently has sufficient demand to attract foreign international airlines with long haul flights. (Business Plan - Reorienting CAA, p.13)

Thus, for the sake of financial benefits, the consultants suggested that all international traffic should be directed towards to Karachi thus ensuring the cessation of 'reduced travel time and cost for passengers'.

The second message was that there was a "lack of business knowledge and skills". Success was determined at the outset by the consultants in terms of firm value rather than the safety and comfort of passengers. Now, when the goals were changed in terms of framing the objectives in terms of profit and value, it became easy for the consultants to suggest that relevant knowledge is missing with CAA at the moment because CAA predominantly comprises technical managers whose expertise is in aviation-related matters. This ploy enabled the consultants to bring CAA to the turf that the consultants supposedly know better than CAA management - business and profit making. Throughout the report, there was a consistent effort to emphasize the lack of business knowledge on the part of CAA and the value of this knowledge. Sometimes it was direct:

"At this time, CAA employs some management talent. However, real-life business experience is scarce..." (ibid., p.5).

In order to emphasize the value of this 'knowledge' that is lacking with CAA, which only the consultants possess or the newly hired employees would possess, it was underscored that the 'Compensation structure of CAA is not competitive... CAA should be prepared to pay competitive remuneration in order to attract the right talent' (ibid., p.5). 
Another suggestion by the consultants, which was designed to emphasize the lack of knowledge on the part of CAA management, was the hiring of consultants. For example, regarding the hiring of fresh talent with business knowledge, the consultants suggested in their report that

"The Board should engage a human resource consultant to identify and attract managers from the commercial market" (ibid., p.6).

Thus, the consultants suggested in their report hiring two more consultants to help CAA implement various business-related recommendations. Once the new mission of the organisation was set and the deficiencies of the current CAA setting to achieve this mission was established, then came a barrage of familiar private sector management control techniques - a state-of-the-art management information system, a new performance measurement system whereby financial incentives are linked to achieving pre-set profit targets, process improvement techniques for labour efficiency, and so on.

One of the most important control problems for managers of capitalistic organisations is the intensification of labour (Uddin and Hopper, 2001; Burawoy, 1979; Sturdy, 1997 a\&b). At the same time, consultants are aware of resistance that may come from clients due to their perceptions of the consultants' role of serving as the 'axeman of capital' (Sturdy, $1997 \mathrm{a} \& \mathrm{~b}$ ). Consultants usually chop middle management heads, but at times, the consulting process may lead to a few senior management heads rolling (Sturdy, $1997 \mathrm{a} \& \mathrm{~b}$ ). This is a perception that consultants try and erase from clients' minds, as they think it is crucial for conducting successful consulting assignments and for obtaining further business from the same client (Sturdy, 1997 a\&b). The same strategy was followed in CAA's case. Thus, money spent on one group (lower level employees) was projected in the report as sheer wastage that needed to be controlled, whereas money spent on the second group (higher management) was 'presented' as a strategic move essential for making this a billion dollar value firm. For example, in the report, it was 
mentioned that labour productivity was a big problem that was going to drag the profitability down in the future (Business Plan - Reorienting CAA, p.13). The consultants also expressed their 'displeasure' that financial gains that could have been achieved through closing unprofitable airports would not be achieved since workers cannot be fired (ibid., p.10). The consultants in the report also suggested that senior managers should have the right to fire employees if they are not satisfied with their performance: "Good performance should be a source of financial rewards whereas consistent poor performance should lead to separation from employment." On the other hand, the report remained silent on contentious issues such as 'managerial productivity' or the salary differential between PG-1 and PG-12 (which was more than twenty times) or the proportion of labour costs to the total staff costs or how much money would be saved by redundancy. The report even suggested establishing at least four further director-level (PG-11) positions (p.15). A director-level position would obviously be supported by further hiring at general-manager level (PG-10) and/or corporate managers (PG-9). These business managers should be hired at 'competitive market prices', according to the report.

\section{The consultants' report: Client's Strategies}

The report was circulated amongst the top management of CAA, i.e., members of Board of Directors and senior ranking officials. It was less than convincing to the senior management even though it was sympathetic to them. The Board of Directors stopped the balance payment to the consultants on the basis that the 'consultants have not finished their job'. The consultants, on the other hand, demanded the release of the rest of the fee as, according to them, they had done the job agreed upon in the terms of reference of the assignment. The matter became confused and resultantly neither consultant came back to do the detailed work CAA management apparently expected, nor did the CAA board release the rest of the payment. The interviews with the managers revealed a number of reasons why the report was rejected. The common belief among managers interviewed, including the senior management, was that "they didn't tell us anything 
new, anything that we didn't know already". The consultants' report was widely believed to be a recycling of some opinions expressed by managers during their interviews with the consultants: "You see, these were young boys, who interviewed a lot of us (senior managers). All that we said during interviews was compiled in their report. Is this what consultants do? This is not what consultants are supposed to do". Another concern raised by many was that the report somehow appeared somewhat 'superficial': 'They told us what to do, but didn't tell us how to do it'. According to the management of CAA, the consultants' job was to provide a complete blueprint of how to reach that billion dollar value mark. However, the consultants showed them only the end target but did not tell them as to how achieve it. The interviewees also pointed out the issue of 'save your skin'. For example, managers complained: "They gave us a thin report comprising a few pages. If we had not objected, someone would have asked us the question, 'Did you spend half a million dollars for these few pages?' We saved our skins by objecting to the report upfront and stopping the rest of the payment." There was also another issue for managers, which possibly persuaded the management to follow the 'save your skin' line: the consulting firm not being the least expensive bidder for the job. Nevertheless, it seems managers took deliberate strategies to undermine the report pointing out some obvious failings. The following summarises three major issues that managers had with the report.

\section{The profit argument}

Even though the report was probably perfectly geared towards the problems and anxieties of the management of capitalistic organisations, it was widely believed by the CAA managers to be inappropriate for a public sector organisation. In terms of profit focus, CAA management was quite satisfied with being one of the very few public sector organisations in Pakistan that was

profitable, although they believed that there was potential for the effective utilization of large real estate resources available to CAA. One former DG commented, "The only area that requires a commercial focus is the real estate development within CAA'. On the contrary, the consultants' 
report suggested that profit focus should be a more pervasive concern and should cover the entire range of activities of CAA. This was a somewhat 'strange' suggestion to many managers for an organisation that has worked since its beginning on the different priorities, as pointed out the first DG of CAA: "Safety, passenger comfort and profitability were our main priorities-in the order described". For many managers, profitability is a means of furthering investment in infrastructure development that could enhance safety and passenger comfort: "We wanted ...to earn and burn (on infrastructure development)," commented the first GM of Finance. The non-profit nature has also been reflected in the way the income statements have been produced over the years where profit has been seen as an 'excess of revenue over expenditure'. The consultants in their report inversed this concept of 'profitability for safety and comfort' with 'safety and comfort for profitability', as reflected in their newly devised mission statements of three functions (ibid., p.3). This was obviously in direct contradiction with the beliefs of actors involved including senior management.

\section{The labour intensification}

Another strategy employed by the consultants that, at least in theory should work well in capitalist organisations, was the control and intensification of labour. The consultants very emphatically highlighted low labour productivity and suggested 'techniques' to overcome this problem including 'process improvements', a new performance measurement system including clauses for the termination of poorly performing labour. To many managers, it was unclear how the consultants came to this conclusion, as they did not do any detailed research on the subject. Nevertheless, managers considered it impossible to implement these techniques for a number of reasons. First, while the consultants thought there was an excess of labour, a great part of it comprises personal support staff by all managers, senior and junior, depending upon their seniority. For example, every director has two lower level employees for their household chores. Then there is a battery of servants and support staff, like drivers, secretaries, steno- typists, peons 
and so on for all managers depending upon their positions. Reducing the workforce would reduce the benefits that senior managers receive free of cost from the organisation. A former DG of CAA revealed: "I know that N.K. (chief executive of a private airline in Pakistan) makes his own coffee. Has his laptop and works on it on his own and probably picks up his own phone. Chief Executive's secretariat comprises a few men other than the Chief Executive himself. But you see, after serving Pakistan Air Force for more than twenty years, I am not used to this. I cannot make my own tea and do not know how to type". Secondly, it is an ideological issue on which there is some degree of consensus amongst senior management in CAA (especially those who are themselves government servants, which effectively means everyone except two members of the board who are from the private sector). Government jobs are considered as less well paid, but the upside is that there is job security. Anyone who joins the government service is sure to remain in the job until he/she reaches retirement age. Firing employees or threatening to fire employees is considered to be a unilateral revocation of an unwritten contract with the employee after he/she has decided to join the government service. One corporate manager justified this saying, "You see, a man who joined CAA fifteen years ago made a decision then that he does not want big salary, but job security. If he wished to, he could have joined Shell or $P \& G$, made more money and accepted the risk of being fired. But he did not choose that. Now after fifteen years, when he is so old that no one will hire him, you are telling him that he can be fired".

\section{Independent management of airports}

Managers at CAA were also perplexed and very critical of the other main recommendation, which was the independent management of airports. This recommendation was based on the apparent conflict between regulatory and airport management at CAA. Managers did not seem to agree with the consultants' report at all. According to almost all managers, the problem was misunderstood and the solution was misplaced. They argue, from the beginning, that the regulatory arm of the organisation that was responsible for granting routes and so on was 
independent; there was not a single manager in the regulatory directorate that was also doing the airport management job. So, the question of role conflict would not arise at all and 'absence of clear ranking or prioritisation' was an irrelevant issue. The consultants' conclusion that many decisions are made at the level of the board and even the ministry due to role conflict was simple naïve, as many interviewees opined. The ministry's involvement in the affairs of CAA was due to the nature of the relationship between different ministries and CAA, the power that these ministries enjoy vis-à-vis CAA, the interests of rulers (political or military) and weak judicial mechanisms. Many decisions were made at ministry level because of the power of the ministries and their vested interests rather than being due to some 'lack of prioritisation of objectives' on the part of CAA. This kind of analysis seemed to provide managers with further arguments regarding the consultants' failure to understand CAA's business specifics. The chairman of the Board of Directors even argued, "They tried to fool us. They simply suggested private sector management techniques without doing any proper analysis." The fear of losing jobs, in particular among the middle-level managers, may have also contributed to the severe criticisms put forward by the managers of the recommendation. Most of the managers believed this was a stepping stone to the privatization of airports and the eventual laying-off of employees.

Overall, the senior management found the report very superficial and thought that what these consultants were suggesting was inappropriate and inapplicable. In addition to this, the CAA management concluded that the report did not conform with the Prime Minister's secretariat's requirements. The demand had been for a business plan giving an accurate picture of revenue, assets, liabilities, proposals for income generation from international as well as domestic routes, its land bank, constructed premises and the potential for tourism,"16 (Asia Plus, 2004). However, the business plan submitted by the consultants does not seem contain any figures whatsoever, except for the vision statement of making CAA a ' 1 billion dollar' value firm. The report was about 'strategic enablers' and 'strategic initiatives', but never quantified what these enablers and 
initiatives will translate into. This rendered the business plan useless for the purpose of senior management and gave an impression of 'superficiality' to the whole report. Now that there were serious doubts about the 'quality of product' that they had received, the risk of some institutional player catching them for paying such an excessive amount for this ' 16 page report' loomed even larger than before. The senior management had to act quickly to protect themselves against any 'risk' to which the consultants had exposed them. They immediately declared the report to be 'incomplete' and asked the consultants to revise and resubmit a 'complete report' and until then, instructed the organisation to stop the balance of payment to the consultants.

\section{Concluding Remarks}

This paper reported on a case study of a consulting assignment on management accounting change carried out in a public sector organisation in Pakistan. The evaluation of the consulting assignment is based on two important aspects. First, it identifies the structural conditions facing managers of public sector firms. These structural conditions push the agents within these structures to act in a certain manner, i.e., tendencies. However, these structures do not do the acting; it is the actors or agents within these structures who have to act and these actors are not mere cultural dopes or role bearers (Sayer, 1992, p.97). Action is still a skilled accomplishment that requires practical knowledge on the part of the actors (Sayer, 1992, p.96). Thus, the second part of the analysis focused on the actions of actors and their reasons - the strategies of actors, i.e., both the consultants and client managers. We believe the analysis conducted has led to a better understanding of the dynamics of consulting within public sector firms. This analysis also sheds light on an area that has been of immense interest to researchers on management consulting, i.e., the nature of the relationship between consultants and clients. 
The paper gives details of the structural conditions of CAA in Pakistan. We argue that these structural conditions lead to tendencies (to act) on the part of managers that are little different from the tendencies of managers working in a typical capitalist firm. These structural conditions and resulting tendencies have implications for the relationship between client and consultant. For example, the consultants were hired by CAA management primarily to combat the structural pressures put on them. This lends support to the structural view of management consulting where consultants are hired primarily by managerial groups as pawns in their own games of vested interests as compared to the strategic view, which suggests the hiring of the consultants was an outcome of the strategies adopted by the consultants (Fincham, 1999). Furthermore, since the structural conditions and associated uncertainties being faced by managers of CAA were not alleviated by the knowledge brought by the consultants' strategy (Sturdy, $1997 \mathrm{a \& b}$ ), the relationship between client and consultant in this scenario tended to be that of an independent client and a dependent consultant. Higher profits and controlling labour and middle management to extract the maximum benefit from them were not the concerns of public sector managers of the case firm and hence the higher profit and tougher management control mantra sold by the consulting firm did not allay their fears and concerns (Sturdy, 1997 a\&b). The structural conditions faced by managers of CAA are very similar to those of other public sector organisations in Pakistan. These results are similar to those of previous studies on public sector organisations, especially in emerging economies (Uddin and Hopper, 2001; Rahman and Lawrence, 2001; Wickramasinghe and Hopper, 2005). In addition to this, reported research on management accounting and control on emerging economies has often cited similar circumstances, for example, a high level of interference by politicians in the running of public sector entities, the lack of profitability concerns and the minimal use of modern day management control practices, for example, Uddin and Hopper (2001) and Uddin and Tsamenyi (2005). This effectively means that in public sector firms operating in emerging economies, structural conditions are most likely to tilt the balance of power in favour of the client as compared to 
consultants. Fincham (1999) criticised the structural and strategic approach to management consulting that favours either client or consultant in terms of the balance of power. He instead argued that the relationship should be 'open-ended' and 'structurally symmetrical'. Which way the balance of power will tilt will depends upon contingent factors. While agreeing with this in general, we would argue, based on this research, that the structural conditions prevalent in most emerging economies may always tilt the balance in favour of the client as compared to consultants.

However, we would not like to argue that what led to the rejection of report were merely structural pressures. As Archer (1995) argues, structure forces no one; it simply assigns differential price tags to different courses of action. The course of action taken by agents is determined by agents' subjective assessment. It was still possible for the client management team not to reject the consultants' report or not to stop the balance of payment. However, in this case, they had to run the risk of an institutional player catching them later on. Obviously, this risk and the price associated with this risk (loss of reputation, loss of job and so on) are determined subjectively by the client management team. In CAA's case, the management became quite conscious of the apparent 'quality' of the advice coming from the consultants' actions. The report, overall, could not convince the clients to the extent that they could justify the reforms to other stakeholders/higher authorities. Strategies such as tougher management control and higher profitability seemed irrelevant to the client. In other words, the consultants' recommendations were not convincing enough for the client (CAA management) to take the risk of accepting the proposal. Previous studies have argued that consultants, in order to establish their legitimacy, take up a client's problems and redefine them in a manner where there is a nice fit between the newly defined problem and consultants' area of expertise (Bloomfield and Danieli, 1995; Fincham, 2003). The consultants did precisely this in CAA's case. They were hired to prepare the business plan of the organisation and they suggested changing the entire business of the organisation in the 
process. As described earlier, in the business plan, the CAA philosophy of profitability for the safety and comfort of passengers was inverted to the safety and comfort of passengers for profitability. Once they had redefined the problem in profit terms, it became easy for the consultants to bring out their 'expertise' in the area. However, this redefinition has to be done in a manner in which a buy-in is created on the client side. This requires, among other things, a thorough understanding of the client's knowledge about its internal business (Fincham, 2003). Once the consultants have this knowledge, it becomes possible for them to blend this knowledge with the 'market knowledge' that they bring to the table (Fincham, 2003).In CAA's case, the consultants' report gave the impression to CAA management that they had poor knowledge of internal business dynamics. Comments in the consultants' report, such as 'decision-making is done at the level of ministry due to role conflict' were repeatedly used by client management to argue against the consultants' understanding of the decision-making process in CAA. The consultants' 'market knowledge', e.g., modern day management accounting and control practices, did not convince CAA management, as the report itself was believed to have been based on a poor understanding of the internal business situation of CAA. To sum up, the consultants' report and strategies combined with structural pressures on the client management team led to the eventual action by the client, i.e., rejection of the consultants' report.

The paper contributes to the accounting literature on management consulting and accounting changes, which is almost non-existent especially in the public sector in emerging economies. Drawing on Fincham's (1999) notion of an 'integrated perspective', the paper provides robust explanations of the role of management consulting in the public sector in emerging economies. The paper also further develops Bhaskar's work $(1975,1979,1997)$ and Archer's work on the structure vs agency debate in accounting literature drawing on case study evidence on management consulting, the role of clients and their impact on accounting changes in CAA. We believe Bhaskar's conceptualization of structure and agency and Archer's methodological 
guidelines provided clarity theoretically and methodologically to explain the events at CAA (Modell, 2009; Aherns, 2008). The application of the notion of structure and agent and their interrelationship provided us with a greater understanding of consultants' and client's strategies and their structural constraints, which ultimately led us to understand the outcomes of the management consultants' interventions at CAA.

Lastly, we would like to issue a caveat. A direct interview with the consultants could have enabled us to understand the rationale for the suggestions they made. However, as a major consulting firm, the structural conditions and insecurities to which members of consulting firms are exposed are well documented in the literature (Sturdy, 1997a; 1997b). Nevertheless, direct interviews with the consultants would have provided further insights on the issues raised by the clients.

\section{References}

Abrahamson, E. \& Eisenman, M., (2001), Why management scholars must intervene strategically in the management knowledge market. Human Relations, 54, pp. 67-75.

Ahrens, T. (2008) 'Overcoming the subjective-objective divide in interpretive management accounting research', Accounting, Organizations and Society 33(2-3) pp. 292-297

Alvesson, M. and Johansson, A.W. (2002) 'Professionalism and Politics in Management Consultancy Work' in Critical Consulting: New Perspectives on the Management Advice Industry (edited by: Timothy Clark and Robert Fincham) Wiley-Blackwell

Alvesson, M. (1993) 'Organisations as Rhetoric: Knowledge Intensive Firms and the Struggle with Ambiguity', Journal of Management Studies, Vol. No. 30 (6)

Anwar, M. (1995) 'Social Networks of Pakistanis in UK: A Re-evaluation' published in The Urban Context: Ethnicity, Social Networks and Situational Analysis edited by Roger, A. \& Vertovec, S. Berg Publishers, UK

Archer, M.S. (1995) 'Realist social theory: the morphogenetic approach' Cambridge University press

Armstrong, P. (1989) 'Management Labour Process and Agency', Work, Employment and Society, Vol.3 (3) 
Baritz (2005) 'Servants of Power', in Critical Management Studies: A Reader (Editors) Chris Grey \& Hugh Willmott

Bhaskar, R. $(1975,1997)$ ‘A Realist theory of science', Verso, London

Bhaskar, R. (1979) 'Possibility of naturalism', Hassocks, Harvester

Bloomfield, B., and Danieli A. (1995) 'The Role of Management Consultants in the Development of Information Technology: The Indissoluble Nature of Socio-Political and Technical Skills.' Journal of Management Studies 33 (1): 27-46.

Burawoy, M. (1979), Manufacturing Consent : Changes in the Labor Process Under Monopoly Capitalism, University of Chicago Press

Clark, T and Greatbatch, D. (2002) 'Knowledge Legitimation and Audience Affiliation through Story Telling: The Example of Management Gurus' (edited by) Timothy Clark and Robert Fincham, Wiley-Blackwell

Clark, T. (1995) 'Managing Consultants - Consultancy as the Management of Impressions' Buckingham: Open University Press.

Collins, D. (2003), The branding of management knowledge: Rethinking management 'fads'. Journal of Organizational Change Management, 2003, 16(2), 186-204.

Collins, D. (2004), Who Put the Con in Consultancy? Fads, Recipes and 'Vodka Margarine' Human Relations, 57, pp. 553-572

Diefenbach, T. (2007) 'The Managerialistic Ideology of Organisational Change Management' Journal of Change Management Vol. 20 (1)

Fincham and Clark (2002) 'The Emergence of Critical Perspective on Consulting' in Critical Consulting: New Perspectives on the Management Advice Industry (edited by) Timothy Clark and Robert Fincham, Wiley-Blackwell

Fincham, R. (1999) 'The Consultant-Client Relationship: Critical Perspectives on the Management of Organisational Change', Journal of Management Studies, Volume 36 Issue 3

Fincham, R. (2003) 'The Agent's Agent: Power, Knowledge, and Uncertainty in Management Consultancy', Int'l. Studies of Mgt. \& Org., vol. 32, no. 4, Winter 2002-3, pp. 67-86.

Gabriel, Y. Essai, (2002), On paragrammatic uses of organizational theory - A provocation. Organization Studies, 23(1), 133-51.

Giddens, Anthony (1984) 'The Constitution of Society. Outline of the Theory of Structuration' Cambridge : Polity

Hood, C. (1991) 'A Public Management for All Seasons?’ Public Administration 69: 3-19.

Hood, C. (1995) 'The new public management in the 1980s: variations on a theme', Accounting, Organisations and Society, 20(2/3) 
Hopper, T., Tsamenyi, M., Uddin, S., Wickramasinghe, D. (2009), "Management accounting in less developed countries: what is known and needs knowing", Accounting, Auditing \& Accountability Journal, Vol. 22 No.3, pp.469-514.

Huczynski, A.A. (1993) 'Management Gurus’ (London : Routledge).

Jackson, B. (2002) 'A Fantasy theme analysis of three guru-led management fashions' in Critical Consulting: New Perspectives on the Management Advice Industry (edited by: Timothy Clark and Robert Fincham) Wiley-Blackwell

Jones, H.R. \& Davenport, M. (1972) 'The Pakistani community in Dundee: A study of its growth and demographic structure' Scottish Geographical Journal, 1751-665X, Volume 88, Issue 2, , Pages $75-85$

Laughlin, R. and Pallot, J. (1998) 'Trends, Patterns and Influencing Factors: Some Reflections' in Olson, O., Guthrie, J. and Humphrey, C. (eds) Global Warning! Debating International Developments in New Public Financial Management.

Lapsley and Oldfield (2001) 'Transforming the public sector: management consultants as agents of change', European Accounting Review vol. 10(3)

Llewellyn, S., (2007), "Case studies and differentiated Realities", Qualitative Research in Accounting \&Management, Vol. 4 No. 1, pp. 53-68.

McKenna, C.D., (2001), The World's Newest Profession: Management Consulting in the Twentieth Century, Enterprise \& Society, No. 2, pp. 673-679.

Modell, S., (2009), In defence of triangulation: A critical realist approach to mixed methods research in management accounting, Management Accounting Research, Vol. 20, pp. 208-221

Nabiha, AK. S. and Scapens, R. W. (2005), 'Stability and change: an institutionalist study of management accounting change', Accounting, Auditing \& Accountability Journal, 18(1): 44-73

National Anti-Corruption Strategy (2002) Published by National Accountability Bureau, Islamabad

Pollitt, C. (1995) 'Justification by Works or by Faith', Evaluation 1(2): 133-54

Porpora, D.V. (1992) 'Four Concepts of Social Structure' in Archer et al. (eds) Critical Realism: Essential Readings, London: Routledge Originally Published in Journal of the Theory of Social Behaviour 19(2) (1989)

Rahaman, A.S. \& Lawrence, S. (2001) 'A negotiated order perspective on public sector accounting and financial control', Accounting, Auditing \& Accountability Journal, Volume 14 Number 2 pages. $147-165$

Saint-Martin, D. (1998) 'The new managerialism and the policy of consultants in government: an historical-institutional analysis of Britain, Canada and France', Governance: An International Journal of Policy and Administration, 11(3): 
Sayer, R. Andrew, (1992) Method in Social Science: A Realist Approach, 2nd Edition, London, Taylor \& Francis

Sayer, R. Andrew, (2000) Realism and Social Science, London, Sage

Stones, R. (2005) ‘Structuration Theory’ Palgrave Macmillan

Sturdy, A. J. (1997, a) 'The Consultancy Process-An Insecure Business?' Journal of Management Studies

Sturdy, A. J. (1997, b) 'The dialectics of consultancy', Critical Perspectives on Accounting, 8:

Transparency International Country Study Report on Pakistan (2003), Published by Transparency International, Berlin, Germany

Tsoukas, H. (2001) 'What is Management? An outline of a Metatheory' in Ackroyd Stephen (Editor) Realist Perspective on Management and Organisation Florence, KY, USA:Routledge, P 38

Uddin, S., (2009) Management Accounting in a private manufacturing company: Rational VS Familial/Traditional Control, Critical Perspectives on Accounting, forthcoming.

Uddin, S. and Hopper, T. (2001) 'A Bangladesh soap opera: privatisation, accounting, and regimes of control in a emerging economy', Accounting, Organisations and Society, 26: 643-72.

Uddin, S. and Tsamenyi, M. (2005) 'Public Sector Reforms and the Public Interest: A Case Study of Performance Monitoring in a Ghanaian State-Owned Enterprise (SOE)', Accounting, Auditing and Accountability Journal

Wickramasinghe, D. and Hopper, T. (2005) A cultural political economy of management accounting controls: a case study of a textile Mill in a traditional Sinhalese village, Critical Perspectives on Accounting $16: 473-503$

Willmott, R. (2000) 'The Place of Culture in Organisation Theory: Introducing the Morphogenetic Approach', Organisation, 7 (1), pp 95-128.

Zaidi, S.A. (1999) 'Issues in Pakistan Economics', Oxford University Press.

\section{Table One}

\begin{tabular}{|l|l|l|l|}
\hline \multicolumn{2}{|c|}{ Hierarchy wise Summary of Interviewees } & \multicolumn{2}{l|}{$\begin{array}{l}\text { Years of employment wise summary of } \\
\text { Interviewees }\end{array}$} \\
\hline $\begin{array}{l}\text { Managerial hierarchy } \\
\text { level }\end{array}$ & $\begin{array}{l}\text { No of persons } \\
\text { interviewed (including } \\
\text { past and present } \\
\text { managers) }\end{array}$ & Details & $\begin{array}{l}\text { Years } \\
\text { Experience }\end{array}$ \\
\hline Pay Group 11 and 12 & 14 & Average experience & 15 years \\
\hline
\end{tabular}




\begin{tabular}{|l|l|l|l|}
\hline (Top Management) & $\begin{array}{l}\text { of persons } \\
\text { interviewed }\end{array}$ & \\
\hline $\begin{array}{l}\text { Pay Group 10 (Upper } \\
\text { Middle Management) }\end{array}$ & 09 & $\begin{array}{l}\text { Minimum } \\
\text { experience }\end{array}$ & 01 year \\
\hline $\begin{array}{l}\text { Pay Group 7-9 (Middle } \\
\text { Management) }\end{array}$ & 10 & $\begin{array}{l}\text { Maximum } \\
\text { experience }\end{array}$ & 26 years \\
\hline $\begin{array}{l}\text { Pay Group 1-6 and Daily } \\
\text { wagers (Lower level } \\
\text { employees) }\end{array}$ & 15 & & \\
\hline MoD Representative & 01 & & \\
\hline
\end{tabular}

Table Two: Performance Indicators

\begin{tabular}{|c|c|c|c|c|c|}
\hline Indicators/Year & 2001 & 2002 & 2003 & 2004 & 2005 \\
\hline $\begin{array}{l}\text { Net Surplus Before Tax } \\
\text { (Rupees in '000') }\end{array}$ & 551,675 & 381,443 & 3,094 & 854,708 & $2,417,975$ \\
\hline $\begin{array}{l}\text { Aircraft Movements at All } \\
\text { Airports in Pakistan (numbers) }\end{array}$ & 183,570 & 155,222 & 154,875 & 177,914 & 199,830 \\
\hline $\begin{array}{l}\text { Passenger Traffic at All } \\
\text { Airports in Pakistan (numbers) }\end{array}$ & $12,038,745$ & $9,888,473$ & $10,624,746$ & $11,885,832$ & $13,582,180$ \\
\hline $\begin{array}{l}\text { Cargo Traffic at All Airports } \\
\text { in Pakistan(M. Tons) }\end{array}$ & 252,191 & 237,807 & 268,809 & 298,950 & 333,267 \\
\hline $\begin{array}{l}\text { Aircrafts flying over } \\
\text { Pakistan(route navigation) }\end{array}$ & 72,159 & 52,850 & 70,961 & 90,031 & 105,279 \\
\hline $\begin{array}{l}\text { Cost/Aircraft } \\
\text { handled }\end{array}$ & 29.52 & 31.25 & 35.11 & 32.02 & 29.17 \\
\hline $\begin{array}{ll}\begin{array}{l}\text { Cost/Passenger } \\
\text { handled }\end{array} & \text { Traffic } \\
\end{array}$ & 0.45 & 0.49 & 0.51 & 0.48 & 0.43 \\
\hline Cost/ Ton of Cargo handled & 21.49 & 20.39 & 20.23 & 19.05 & 17.49 \\
\hline $\begin{array}{lll}\begin{array}{l}\text { Cost/Aircraft } \\
\text { Pakistan }\end{array} & \text { flying } & \text { over } \\
\end{array}$ & 75.12 & 91.78 & 70.64 & 63.29 & 55.37 \\
\hline Sensitive Price Index & 4.84 & 3.37 & 3.58 & 6.83 & 11.55 \\
\hline Consumer Price Index & 4.41 & 3.54 & 3.10 & 4.57 & 9.28 \\
\hline Wholesale Price Index & 6.21 & 2.08 & 5.57 & 7.91 & 6.75 \\
\hline
\end{tabular}

Sources: Federal Bureau of Statistics, Government of Pakistan, Civil Aviation Authority, Statistics of Pakistan, 1972-2005, CAA Annual Report 2005.

Figure 1: Structural Conditions facing Senior Managers in Public Sector Entities and resulting tendencies 


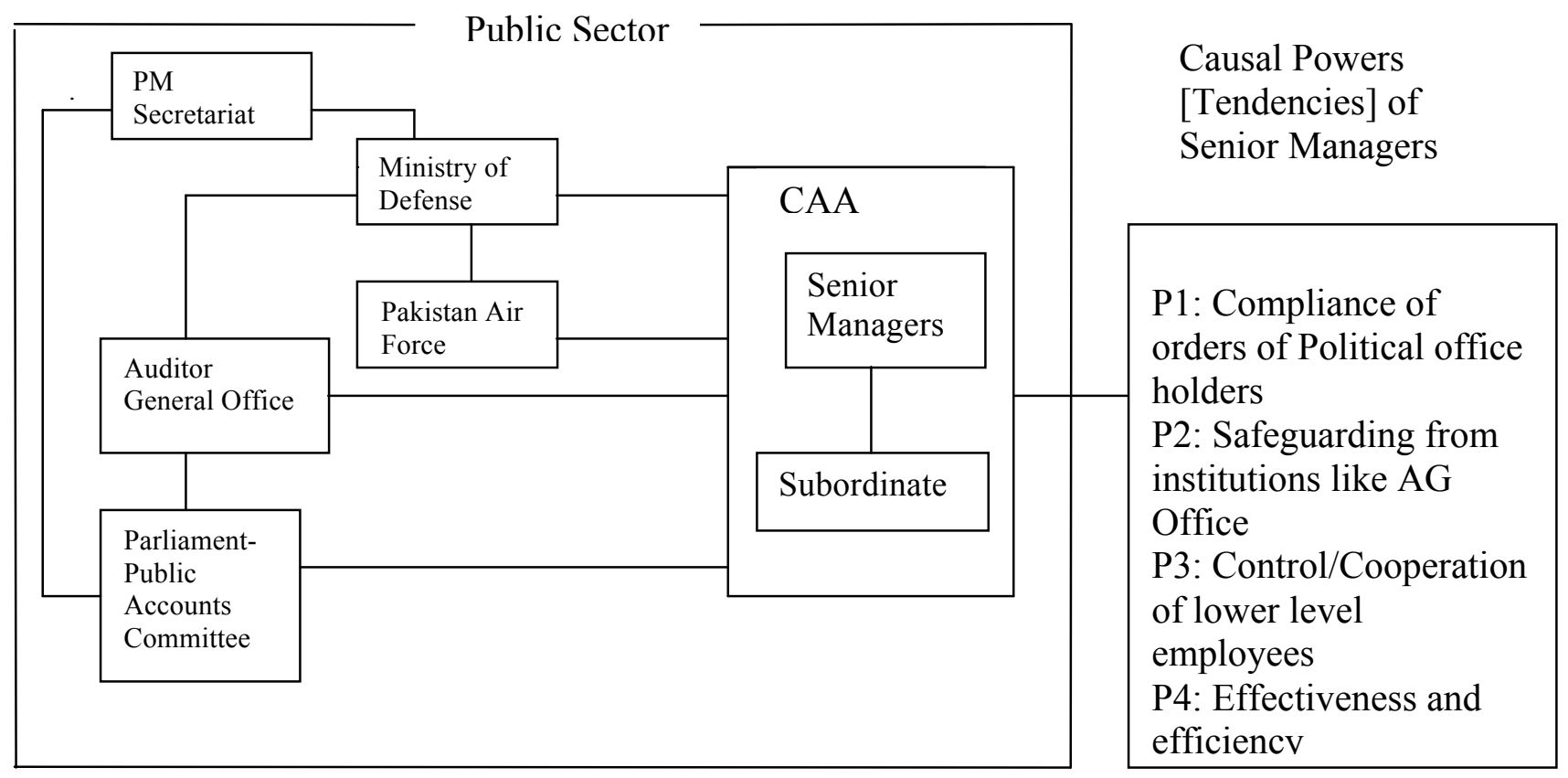

\footnotetext{
${ }^{1}$ One classical school in sociology, namely, methodological individualists, believes that social collectivity (family, business organization, and society) is nothing but the sum total of actions of a number of individual actors. The focus of sociological investigation must be men and their actions, i.e., agents and their actions. On the contrary, the opposite classical school in sociology, namely, collectivists, believes that when individuals combine together to form collectivities, and that these collectivities have properties that are greater than the sum of their parts. Therefore, to investigate these collectivities, we cannot focus on individuals; instead, the focus should be on the properties of these collectivities.

${ }^{2}$ See Sayer $(1992,2000)$ and Archer (1995) for further explanations of the structure and agency debate and Baskar's philosophy, i.e., critical realism.

${ }^{3}$ The paper does not intend to clarify the difference between Giddens and Bhaskar's conceptualisation of structure or the superiority of Bhaskar's approach over that of Giddens. Readers are recommended to read Archer (1995) and Porpora (1998). For a comparison of the two approaches with a more sympathetic attitude towards Giddens, please read Stones (2005).

${ }^{4}$ It is thus the result of structural pressures, i.e., pressures arising out of the 'positions' of managers vis-àvis other positions, such as other managers or labour, that, according to Sturdy (1997), explains tendencies on the part of managers to hire consultants. However, it is not inevitable that these pressures will result in managers always hiring consultants. Similarly, the consultants can be hired due to the operation of different structural mechanisms.

${ }^{5}$ Porpora D.V. (1998) 'Four Concepts of Social Structure'

${ }^{6}$ Archer's (1995) full theory is quite elaborate and sophisticated. We have borrowed only the methodological guidelines in terms of the analytical dualism of structure and agency and their interplay with a temporal dimension.

${ }^{7}$ Interviews with the consultants were not possible, as the consultants were not available during the study. However, we had access to the consultants' report that was submitted by the consultants to management at
} 
the end of the assignment. This report enabled us to understand the analysis done by the consultants, the recommendations they had made, and the 'strategy' that they had adopted for 'selling' their suggestions. As far as structural conditions facing the consulting firm is concerned, these should be the same as with any other capitalistic firm and are well documented in the literature (Sturdy, $1997 \mathrm{a} \& b$ ).

${ }^{8}$ The primary functions of the organization are to provide air navigation facilities for flights flying over Pakistan or landing and taking off at Pakistani airports; to regulate the aviation industry within Pakistan. Regulation business, which will include, for example, giving licenses to pilots and aircrafts, the regular inspection of aircraft to assess their airworthiness, the inspection of navigational equipment and landing strips, and a regular review of the fitness of pilots to fly the aircrafts; and to manage the airports of the country including the commercial activities taking place on these airports

${ }^{9}$ The Prime Minister himself was an ex-manager of a top multinational corporation and spent all his working life in USA (see 'Business as Usual' by Iffat Idris on Al Ahram Weekly, 01/07/2004).

10 'Pakistani Gov't Tells Caa To Prepare Business Plan In 30 Days', Asia Pulse, December 2, 2004

${ }^{11}$ Even though there was nothing particularly unusual about this 'revelation' given that these huge loans had already been paid off by CAA by the time cabinet meeting took place

12 'Pakistani Gov't Tells Caa To Prepare Business Plan In 30 Days', Asia Pulse, December 2, 2004

${ }^{13}$ It was not known to the researchers how much CAA initially agreed to pay to the consulting firm, but after negotiations in the terms of reference, CAA finally agreed to pay $\$ 0.5 \mathrm{~m}$.

14."Aminullah Chaudhry, CSP [Civil Services of Pakistan], Director General of Civil Aviation Authority (DGCAA), and secretary, Aviation Division, Government of Pakistan received a telephone call a little after $6 \mathrm{pm}$ on 12 October 1999. Aminullah Chaudhry took the call and the operator at the other end informed him that the prime minister of Pakistan wished to speak to him. Aminullah Chaudhry recollects that the prime minister, Mian Muhammad Nawaz Sharif, came on the line and, after an exchange of greetings, inquired from him whether he was aware of the flight details of the chief of army staff's (COAS) aircraft return to Pakistan. He submitted that he was not. The prime minister then instructed him to find out these details and ensure that this particular flight should not be allowed to land at any airport in Pakistan. The DG of CAA, without realizing the consequences emanating from this illegal order of the prime minister, issued instructions that the flight PK 805 carrying the COAS and other passengers should not be allowed to land anywhere in Pakistan. Aminullah Chaudhry was indebted to the prime minister for awarding him such a prestigious position. He had also held the additional charge of the post of the secretary, Aviation Division, Government of Pakistan since May 1999. He was a seasoned bureaucrat and a grade 21 officer, who had 32 years of service to his name. He knew the temperament of the prime minister quite well. He was absolutely clear in his mind that any defiance of the prime minister's directive in this given situation would result in grave implications for him, both professionally and otherwise". Excerpts from book titled PK 805: but the truth by Muhammad Ilyas Khan, Royal Book Company quoted in Dawn News January15, 2002 (my italics).

${ }^{15}$ It is important to note that from its inception, to highlight the non profit nature of the organization, CAA calls its income statement an income and expense statement and instead of calling the bottom line profit, it is described as an excess of income over expenses.

16 ‘Pakistani Gov't Tells Caa To Prepare Business Plan In 30 Days', Asia Pulse, December 2, 2004 